\title{
The Application of Different Biological Remediation Strategies to PCDDs/PCDFs Contaminated Urban Sediments
}

\author{
Magdalena Urbaniak ${ }^{1,2, *}$, Anna Wyrwicka ${ }^{3}{ }^{\circ}$, Grzegorz Siebielec ${ }^{4}$, Sylwia Siebielec ${ }^{4}$, \\ Petra Kidd ${ }^{5}$ (D) and Marek Zieliński ${ }^{6}$ \\ 1 Department of Applied Ecology, Faculty of Biology and Environmental Protection, University of Lodz, \\ Banacha 12/16, 90-237 Lodz, Poland \\ 2 European Regional Centre for Ecohydrology of the Polish Academy of Sciences, Tylna 3, 90-364 Lodz, Poland \\ 3 Department of Plant Physiology and Biochemistry, Faculty of Biology and Environmental Protection, \\ University of Lodz, Banacha 12/16, 90-237 Lodz, Poland; anna.wyrwicka@biol.uni.lodz.pl \\ 4 Institute of Soil Science and Plant Cultivation-State Research Institute, Czartoryskich 8, 24-100 Pulawy, \\ Poland; gs@iung.pulawy.pl (G.S.); ssiebielec@iung.pulawy.pl (S.S.) \\ 5 Instituto de Investigaciones Agrobiológicas de Galicia (IIAG), Consejo Superior de Investigaciones \\ Científicas (CSIC), Santiago de Compostela 15706, Spain; pkidd@iiag.csic.es \\ 6 Nofer Institute of Occupational Medicine, Teresy 8, 91-348 Lodz, Poland; marekz@imp.lodz.pl \\ * Correspondence: m.urbaniak@unesco.lodz.pl or magdalena.urbaniak@biol.uni.lodz.pl
}

Received: 5 July 2019; Accepted: 16 September 2019; Published: 20 September 2019

\begin{abstract}
Our aim was to assess the efficacy of four different bioremediation strategies applied to soil treated with urban sediments for alleviating soil phytotoxicity (examined using Lepidium sativum), by removing polychlorinated dibenzo- $p$-dioxins (PCDDs) and polychlorinated dibenzofurans (PCDFs), and mitigating the toxic effect on plants by the applied sediment: (1) Natural attenuation, (2) phytoremediation with the use of two plants Tagetes patula L. and Festuca arundinacea, (3) rhizobacterial inoculation with Massilia niastensis p87 and Streptomyces costaricanus RP92 strains, (4) rhizobacteria-assisted phytoremediation with both plants and strains. The applied sediment had a positive influence on L. sativum growth ( $90 \%$ higher than in the unamended soil), mostly due to its high content of nutrients, mainly $\mathrm{Ca}$ and $\mathrm{Fe}$, which immobilize pollutants. The positive effect of sediments continued for up to 10-week duration of the experiment; however, the rhizobacterial inoculated samples were characterized by higher growth of L. sativum. The application of rhizobacteria-assisted phytoremediation further increased the growth of L. sativum, and was also found to improve the efficiency of PCDD/PCDF removal, resulting in a maximum $44 \%$ reduction of its content. This strategy also alleviated the negative impact of urban sediments on T. patula and F. arundinacea biomass, and had a beneficial effect on protein and chlorophyll content in the studied plants.
\end{abstract}

Keywords: urban sediments; PCDDs/PCDFs; rhizobacterial inoculants; bioremediation; phytoremediation

\section{Introduction}

The urban water ecosystems, located downstream of city landscapes, often become reservoirs for a variety of pollutants originating from atmospheric deposition, as well as urban runoff, storm water outlets, industrial waste and combined sanitary overflows [1-3]. To minimize the inflow of such pollutants to river ecosystems and their further transport along the river continuum, small dam reservoirs, sedimentation ponds and biofilters might be used. These constructions create ideal conditions for the sedimentation and deposition of particulate matter by decreasing the flow velocity, thus acting as efficient traps for associated compounds of urban origin [4-12]. However, the accelerated 
accumulation of sediments and associated pollutants leads to rapid siltation of such constructions, and this requires periodical dredging of the accumulated sediments and their further utilization [7]. These dredged urban sediments are usually stored in landfill areas, where they act as potential hazardous material for the surrounding environment. In addition, this solution creates economic burdens for the municipality due to the need to transport the sediments out of the city.

One promising method of managing the increasing amount of urban reservoir sediments is their direct application within the city limits as soil additives on city gardens and lawns. This type of urban sediment utilization is possible due to their richness in nutrients and organic matter, which improve soil properties and promote plant growth. Nevertheless, urban sediments also contain other compounds with harmful properties, such as heavy metals, pesticides washed out from urban green areas, car oils from streets and parking areas, and a variety of other organic compounds of industrial or anthropogenic origin. One of the most toxic groups of compounds, which have carcinogenic, hepatotoxic, immunotoxic and neurotoxic properties, are polychlorinated dibenzo- $p$-dioxins and polychlorinated dibenzofurans (PCDDs/PCDFs) $[9,10]$. These pollutants are characterized by a wide range of occurrence in the urban water ecosystems, because their main source is the load of domestic and industrial wastewater, atmospheric emission and deposition as well as emission from other sources associated with human activity in the city space such as car traffic [10].

Due to highly hydrophobic characteristics of PCDDs/PCDFs, they undergo rapid deposition in river and reservoir sediments, thus lowering the quality of the urban ecosystem and decreasing its biodiversity. Owing to the toxic properties of $\mathrm{PCDDs} / \mathrm{PCDFs}$, their persistence in the environment and their ability to bioaccumulate in aquatic and terrestrial trophic chains, the European Commission classified them as priority hazardous substances in the field of water policy, and imposed a requirement for EU members to monitor and eliminate them from the environment [13].

A potential approach to be applied for inactivation of urban sediments contaminated with PCDDs/PCDFs is phytoremediation-a method aimed at removal or decomposition of the pollutants using plants. Nevertheless, PCDDs/PCDFs due to their hydrophobicity and hence their strong adsorption by sediment and soil particles, transfer to sediment or soil solution to a very small extent. Consequently, the ability of plants to uptake PCDDs/PCDFs from sediments or soil is very limited [14]. In this situation, plants can be used to promote the continued existence of indigenous soil microorganisms, which are able to biodegrade PCDDs/PCDFs (rhizodegradation). In addition, inoculation of these contaminated sediments with appropriately selected specific single strains or consortia of microorganisms may further increase the efficiency of biodegradation processes.

Such remediation approaches as natural bioremediation with indigenous microorganisms (i.e., natural attenuation), inoculation and phytoremediation can be used separately; however, the most promising solution is for their combined use as part of rhizobacteria-assisted phytoremediation, intended to optimize the synergistic effect of selected plants and bacterial strains. Until now, this approach has been successfully used for cleaning soil contaminated with both organic and inorganic compounds [15-18]; however, no such studies have been performed on the remediation of urban sediments used directly within city limits.

The key step in designing an effective rhizobacteria-assisted phytoremediation strategy is the selection of a suitable plant-bacteria partnership to maximize the removal efficiency of a given pollutant $[15,19]$. Among the plants used in the remediation of contaminated soil, two species are of particular relevance, and are also specific to city gardens and lawns: Tagetes patula L. (Asteraceae) is commonly used as an ornamental plant, whereas Festuca arundinacea Schreb. (Poaceae) is often used in reclamation and as a grass species sown on lawns.

Tagetes patula L., commonly known as French marigold, is a robust and non-fussy plant originating from Mexico, used mainly as an edging plant on herbaceous borders. Marigold produces secondary metabolites, which assist in the remediation of combined contaminated sites [20,21]. It also contains bioactive compounds, which are widely employed as insecticides, fungicides and nematicides [22]; while Festuca arundinacea Schreb., commonly known as Tall fescue, is an evergreen, tuft-forming grass 
with a deep root system. It is a cool-season perennial C3 species native to Europe, frequently used in the phytoremediation of soil contaminated with organic compounds [18,20,23,24].

Among the bacterial strains used for bioremediation, Streptomyces costaricanus RP92, isolated from the rhizosphere of Cytisus striatus, is especially interesting because it can improve the remediation of soil contaminated with chloroorganic compounds such as hexachlorocyclohexane or diesel oils [25-27]. The strain Massilia niastensis P87, isolated from the rhizosphere of Festuca rubra, found growing on mine tailings with elevated concentrations of $\mathrm{Cd}, \mathrm{Pb}$ and $\mathrm{Zn}$ [27], would further improve the bioremediation efficiency of the mixtures of pollutants, including trace metals which accumulate in urban sediments.

Considering the above, our aim was to assess and compare the efficacy of four different environmentally friendly strategies in the remediation of soil contaminated with PCDDs/PCDFs by urban bottom sediment application: (1) natural attenuation, (2) phytoremediation with two selected plant species Tagetes patula L. and Festuca arundinacea Schreb., (3) rhizobacterial inoculation with two selected strains Streptomyces costaricanus RP92 and Massilia niastensis P87, and (4) rhizobacteria-assisted phytoremediation using both sets of plants and bacterial strains given above. At the same time, the effects of urban sediment application and the said remediation strategies on soil phytotoxicity were evaluated. In addition, the plant biomass, total soluble protein content, total chlorophyll content and chlorophyll $\mathrm{a} / \mathrm{b}$ ratio were measured to assess plant response to the applied urban sediments and remediation strategies.

\section{Materials and Methods}

\subsection{Urban Sediments and Soils}

The urban bottom sediments were collected from a sedimentation zone of the sequential sedimentation-biofiltration system located in Lodz, Poland, on the Sokołówka River. The system was constructed to reduce the inflow of particulate matter and a range of organic, inorganic and bacterial pollutants from storm water coming from the most urbanized catchment area of the Sokołówka River.

The system comprises (1) the hydrodynamically intensified sedimentation zone that facilitate the sedimentation and deposition processes, and in this way enable pre-treatment of the inflowing river and storm water; (2) the intensified biogeochemical processes zone, where fine particles are sieved and nutrients are reduced; and (3) intensified biofiltration zone planted with macrophytes (Phragmites australis, Typha latifolia and Acorus calamus) responsible for removal of nutrients and organic compounds $[28,29]$.

Fresh sediments, with a dry matter (DM) content of 35\%, were mixed with agricultural uncontaminated Haplic Luvisol type soil, in a 1:10 proportion and transferred into $2 \mathrm{~kg}$ pots. Prior to mixing, the soil was sieved using a 2-mm sieve.

\subsection{Pot Experiment Design}

The experimental design included four variants:

1. Natural attenuation - uncontaminated soil was mixed with fresh urban sediments, and no plants or bacterial inoculants were added;

2. Phytoremediation-uncontaminated soil was mixed with fresh urban sediments and T. patula $\mathrm{L}$. or F. arundinacea Schreb. were planted;

3. Rhizobacterial inoculation - uncontaminated soil was mixed with fresh urban sediments and $S$. costaricanus RP92 or M. niastensis P87 were added, no plants were grown;

4. Rhizobacteria-assisted phytoremediation — using both the studied plants and bacterial strains (Figure 1).

All the variants were performed in triplicate (three separate pots per one remediation variant).

T. patula L. was seeded at a rate of 15 seeds per pot, which was reduced to 10 plants per pot after germination. F. arundinacea seeds were seeded at a rate of $2 \mathrm{~g}$ per pot. 
Fresh cultures of bacterial strains were grown in 869 liquid medium [30] for $24 \mathrm{~h}$. Five $\mathrm{mL}$ of this pre-culture was then grown for $12 \mathrm{~h}$ in fresh 869 liquid medium. Subsequently, bacterial biomass was collected by centrifugation (6000 rpm, $15 \mathrm{~min}$ ), washed once and re-suspended in $10 \mathrm{mM} \mathrm{MgSO}_{4}$ solutions to an $\mathrm{OD}_{660}$ of 1.0 (about $10^{7}$ cells per $\mathrm{mL}$ ). Each plant pot was inoculated during the germination phase (four weeks after seeding) with $100 \mathrm{~mL}$ of bacterial suspension. The same amount of sterile $10 \mathrm{mM} \mathrm{MgSO}_{4}$ was added to non-inoculated pots. The inoculation was repeated after three weeks using the same procedure.

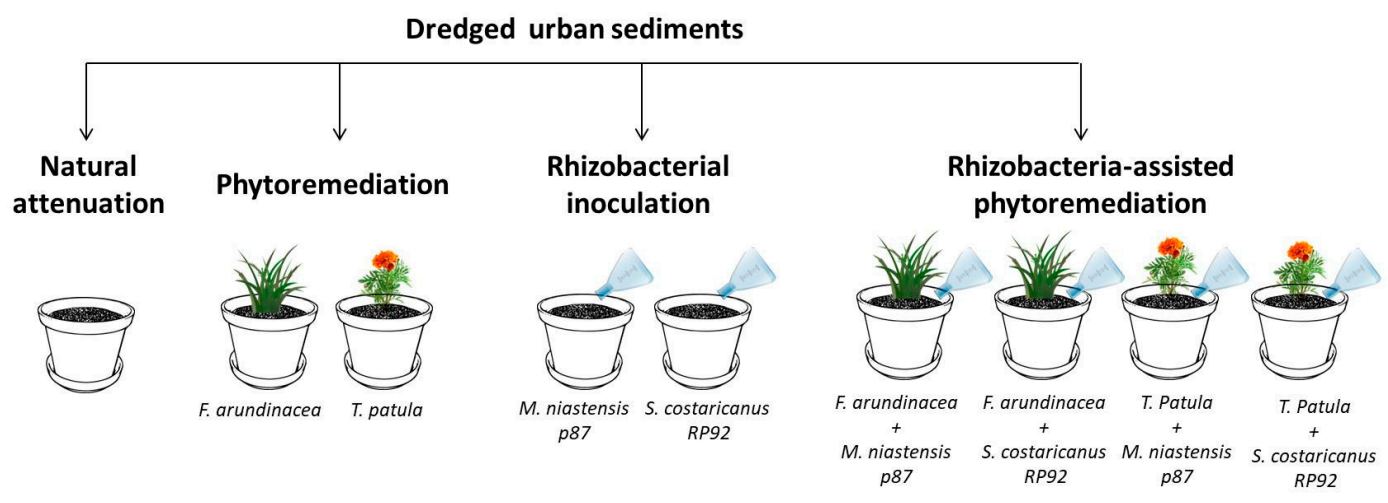

Figure 1. Experiment design.

The pot study was run for a 10 -week period in a greenhouse under controlled conditions, i.e., supplemental light and $27^{\circ} \mathrm{C} / 20^{\circ} \mathrm{C}$ day/night temperatures. After this time, the plants were harvested, the fresh biomass was weighed and the protein and chlorophyll content, as well as the chlorophyll $\mathrm{a} / \mathrm{b}$ ratio, were measured in plant green tissues.

After harvesting, soil from each treatment was mixed, sieved to 2-mm sieve to remove the plant residues, and aliquots of soil were collected for further analyses of PCDD/PCDF concentrations and the phytotoxicity bioassay.

\subsection{Soil Analyses}

\subsubsection{Determination of Physico-Chemical Parameters}

Soil $\mathrm{pH}$ was measured in $\mathrm{H}_{2} \mathrm{O}$ using a 1:2.5 soil:solution ratio. Total $\mathrm{C}$ was measured by combustion with a CN analyzer (Elementar, vario Macro cube, Langenselbold, Germany). The sediment samples were digested for elemental composition analysis in a 3:1 mixture of concentrated $\mathrm{HNO}_{3}: \mathrm{HCl}$ in Teflon PFA vessels in a microwave accelerated reaction system (MarsXpress; CEM Corp., Matthews, NC, USA); total concentrations of elements were analyzed by ICP-MS (Agilent 7500ce, Agilent Technologies Inc., Santa Clara, CA, USA).

\subsubsection{Determination of PCDD/PCDF Concentrations}

For analysis of the concentrations of 17 toxic congeners of PCDD/PCDF, the PN-EN 1948-3 [31] and US EPA Method 1613 [32] were applied. The analysis was carried out based on isotope dilution and high-resolution gas chromatography (HRGC)/high-resolution mass spectrometry (HRMS) using an HP 6890 N Agilent Technologies GC coupled with a high-resolution mass spectrometer AutoSpec Ultima. The detailed description of the applied analytical procedure is depicted in the work by Urbaniak et al. [8]. The obtained concentrations were calculated using Toxic Equivalency Factor (TEF) and expressed as the Toxic Equivalency (TEQ) [33,34].

Quality assurance/quality control procedure was carried out using certified calibration standards. Each analytical series contained sample blank, control, certified reference material and in-house QC samples. Samples' spikes were used also as an additional check of accuracy. Recoveries of ${ }^{13} \mathrm{C}$-labeled PCDDs/PCDFs ranged from $74 \%$ to $146 \%$. Artefacts were estimated using a reagent blank, and 
duplicate analysis enabled to verify the precision that ranged from $2 \%$ to $11 \%$. The obtained LOD values ranged from 0.070 to $0.143 \mathrm{ng} / \mathrm{kg}$ for PCDDs and 0.042 to $0.137 \mathrm{ng} / \mathrm{kg}$ for PCDFs.

\subsubsection{Phytotoxicity Analysis}

The commercially available bioassay Phytotoxkit ${ }^{\mathrm{TM}}$ Test (Microbiotest Inc., Nazareth, Belgium) was used to assess the phytotoxicity of the soil samples [35]. The principle of the test is based on measurement of the inhibition of the length of roots of test species after 3 days of exposure to contaminated soil in relation to a reference soil. For the purpose of this experiment, the dicotyledon Lepidium sativum (L.) was used as a test plant. Uncontaminated soil with no treatment (control) was used as reference soil to assess the impact of urban sediments and various biological remediation strategies on soil phytotoxicity. The sample was classified as toxic when the root length inhibition exceeded $20 \%$ [36].

\subsection{Plant Analyses}

\subsubsection{Determination of Protein Content}

The T. patula L. and F. arundinacea Schreb. leaf extracts were prepared using $50 \mathrm{mM}$ sodium phosphate buffer ( $\mathrm{pH} 7.0$ ) containing $0.5 \mathrm{M} \mathrm{NaCl}, 1 \mathrm{mM}$ EDTA and $1 \mathrm{mM} \mathrm{C}_{6} \mathrm{H}_{7} \mathrm{NaO}_{6}$. Obtained extracts underwent filtration on Miracloth filters and the obtained filtrates were centrifuged (15,000 $\mathrm{g} \times 15 \mathrm{~min})$. The supernatant was used for protein content determinations according to Bradford method [37]. The measurements were performed using a Helios Gamma spectrophotometer (Thermo Spectronic, Cambridge, UK) based on standard curves with Bovine Serum Albumin. The content of protein was depicted in $\mathrm{mg} \mathrm{g}^{-1}$ of fresh mass (FM)

\subsubsection{Determination of Chlorophyll Content}

The T. patula L. and F. arundinacea Schreb. leaves were homogenized in an ice-cold mortar using sodium phosphate buffer, as it was described in point 2.4.1. The obtained homogenate was filtered and analyzed for chlorophyll content according to Porra et al. [38], using a Helios Gamma spectrophotometer (Thermo Spectronic, Cambridge, UK). The chlorophyll content was shown as mg g ${ }^{-1}$ FM.

\subsection{Statistical Analysis}

The two-way ANOVA was performed to test the effect of both inoculation and plants on the soil phytotoxicity, and the effect of sediment and inoculation on plant parameters (biomass, protein content, chlorophyll content, chlorophyll a/b ratio). No statistical analyses were conducted for PCDDs/PCDFs as no replicates are available. For the plant analyses statistical significance was tested separately for each plant (T. patula and F. arundinacea). The post-hoc Duncan test was used to confirm the statistically significant differences. All analyses were performed using STATISTICA 13 software.

\section{Results and Discussion}

\subsection{The Physico-Chemical Properties and PCDD/PCDF Concentrations in Soil, Urban Sediments and Sediment-Amendment Soil}

The soil used in the pot study had a loamy sand texture and the soil $\mathrm{pH}$ was 6.5 . The soil OC content was $11.0 \mathrm{~g} \mathrm{~kg}^{-1}$, which is lower than the average soil OC content in the climate zone including Poland (sub-oceanic to sub-continental) in the European LUCAS program, which was found to be $15 \mathrm{~g} \mathrm{~kg}^{-1}$ [39]. The concentration of PCDDs/PCDFs in soil was low, amounting to $24.8 \mathrm{ng} \mathrm{kg}^{-1}$ and $0.3 \mathrm{ng}$ TEQ $\mathrm{kg}^{-1}$. Similarly, concentrations of potentially toxic trace metals (PTTM) were low and ranged from $0.05 \mathrm{mg} \mathrm{kg}^{-1}$ for $\mathrm{Cd}$ to $28.5 \mathrm{mg} \mathrm{kg}^{-1}$ for $\mathrm{Ba}$ (Table 1). 
Table 1. The physico-chemical characteristics of the collected urban sediment, the uncontaminated soil used in the experiment and the soil mixed in a proportion of 1:10 with the urban sediments.

\begin{tabular}{cccc}
\hline Compound & Urban Sediment & Uncontaminated Soil & Urban Sediment Amended Soil \\
\hline Soil pH & 7.15 & 6.65 & 7.21 \\
OC $\left(\mathrm{g} \mathrm{kg}^{-1}\right)$ & 108 & 11.0 & 19.9 \\
Sum of 17 PCDDs/PCDFs $\left(\mathrm{ng} \mathrm{kg}^{-1}\right)$ & 2170 & 24.8 & 236 \\
TEQ PCDDs/PCDFs (ng TEQ kg & (1) & 8.8 & 2.1 \\
$\mathrm{Mg}\left(\mathrm{mg} \mathrm{kg}^{-1}\right)$ & 7040 & 403 & 1030 \\
$\mathrm{Ca}\left(\mathrm{mg} \mathrm{kg}^{-1}\right)$ & 42,300 & 1020 & 5440 \\
$\mathrm{Fe}\left(\mathrm{mg} \mathrm{kg}^{-1}\right)$ & 32,000 & 3170 & 6140 \\
$\mathrm{Zn}\left(\mathrm{mg} \mathrm{kg}^{-1}\right)$ & 821 & 16.1 & 111 \\
$\mathrm{Cr}\left(\mathrm{mg} \mathrm{kg}^{-1}\right)$ & 62.2 & 5.7 & 10.7 \\
$\mathrm{Cd}\left(\mathrm{mg} \mathrm{kg}^{-1}\right)$ & 1.2 & 0.05 & 0.19 \\
$\mathrm{Ba}\left(\mathrm{mg} \mathrm{k}^{-1}\right)$ & 282 & 28.5 & 51.2 \\
$\mathrm{~Pb}\left(\mathrm{mg} \mathrm{kg}^{-1}\right)$ & 90.1 & 6.5 & 14.9 \\
$\mathrm{Cu}\left(\mathrm{mg} \mathrm{kg}^{-1}\right)$ & 117 & 2.7 & 15.2 \\
\hline
\end{tabular}

The fresh bottom sediments contained $35 \%$ of DM, and OC concentration was $108 \mathrm{~g} \mathrm{~kg}^{-1} \mathrm{DM}$. The sediment $\mathrm{pH}$ was 7.15 . The sediments contained $0.70 \%$ magnesium $(\mathrm{Mg}), 0.52 \%$ potassium $(\mathrm{K})$, $4.23 \%$ calcium $(\mathrm{Ca}), 3.20 \%$ iron $(\mathrm{Fe})$ and $3.71 \%$ aluminum (Al). Among trace elements, only zinc (Zn) concentration exceeded the corresponding Probable Effect Concentration (PEC) value: 821 vs. $459 \mathrm{mg} \mathrm{kg}^{-1}$ [40]. Elevated concentrations were recorded for barium (Ba) and copper (Cu), 282 and $117 \mathrm{mg} \mathrm{kg}^{-1}$, respectively, but these values did not exceed threshold values. However, PCDD/PCDF levels were high, exceeding the $0.85 \mathrm{ng}$ TEQ kg${ }^{-1}$ limit specified in the Sediment Quality Guideline (SQG) (http://ceqg-rcqe.ccme.ca/download/en/245) by more than 10-fold (Table 1).

The application of sediments to soil shifted its $\mathrm{pH}$ from neutral ( $\mathrm{pH}$ 6.65) to slightly alkaline ( $\mathrm{pH}$ 7.21). Also, OC increased to $19.9 \mathrm{~g} \mathrm{~kg}^{-1}$ after the application of sediment. The concentrations of trace elements also increased; however, they remained below the Probable Effect Concentration (PEC). Only the TEQ concentration of PCDDs/PCDFs grew significantly, exceeding the allowable limit of $0.85 \mathrm{ng}$ TEQ $\mathrm{g}^{-1}$ (SQG) by 2.5 -fold as an effect of sediment application (Table 1).

\subsection{The Effects of Urban Sediment Amendment and Applied Remediation Strategies on Soil Phytotoxicity and PCDD/PCDF Concentrations}

The structure of bottom sediments renders them a perfect geosorbent for the mixture of pollutants introduced to the water environment. Consequently, the assessment of their toxicity based on monitoring of hazardous substances, such as heavy metals and PCDDs/PCDFs, does not encompass all the chemical compounds potentially present therein, nor their interactions. In this situation, the bioindication method (biotests) is a more accurate approach to assessing the toxicity of dredged sediments and may provide more useful information about the phytotoxicity and influence on soil [41-43].

In our bioassay, the application of urban sediments to soil was found to have a positive influence on plant growth, stimulating an $89 \%$ increase in L. sativum root length, in comparison to control soil. This increased growth can be attributed to the high nutrient content and greater $\mathrm{Ca}$ and Fe levels, which are known to be capable of immobilizing pollutants, especially trace elements (Table 1). This positive influence of urban sediments fell to $29 \%$ after 10 weeks of the experiment (natural attenuation strategy). However, samples inoculated with rhizobacterial strains were characterized by a better growth of L. sativum in comparison to the non-augmented samples, showing an increase of root growth of $38 \%$ (p87) and 65\% (RP92) in comparison to control samples (Figure 2).The application of inoculation-assisted phytoremediation using both rhizobacterial inoculants and both plants further improves soil quality, with a $97 \%$ increase in L. sativum root growth compared to untreated samples observed in the case of simultaneous application of F. arundinacea and bacterial strain p87. The two-way ANOVA did not confirm, however, the influence of the bacterial inoculation and plants on the soil phytotoxicity. 


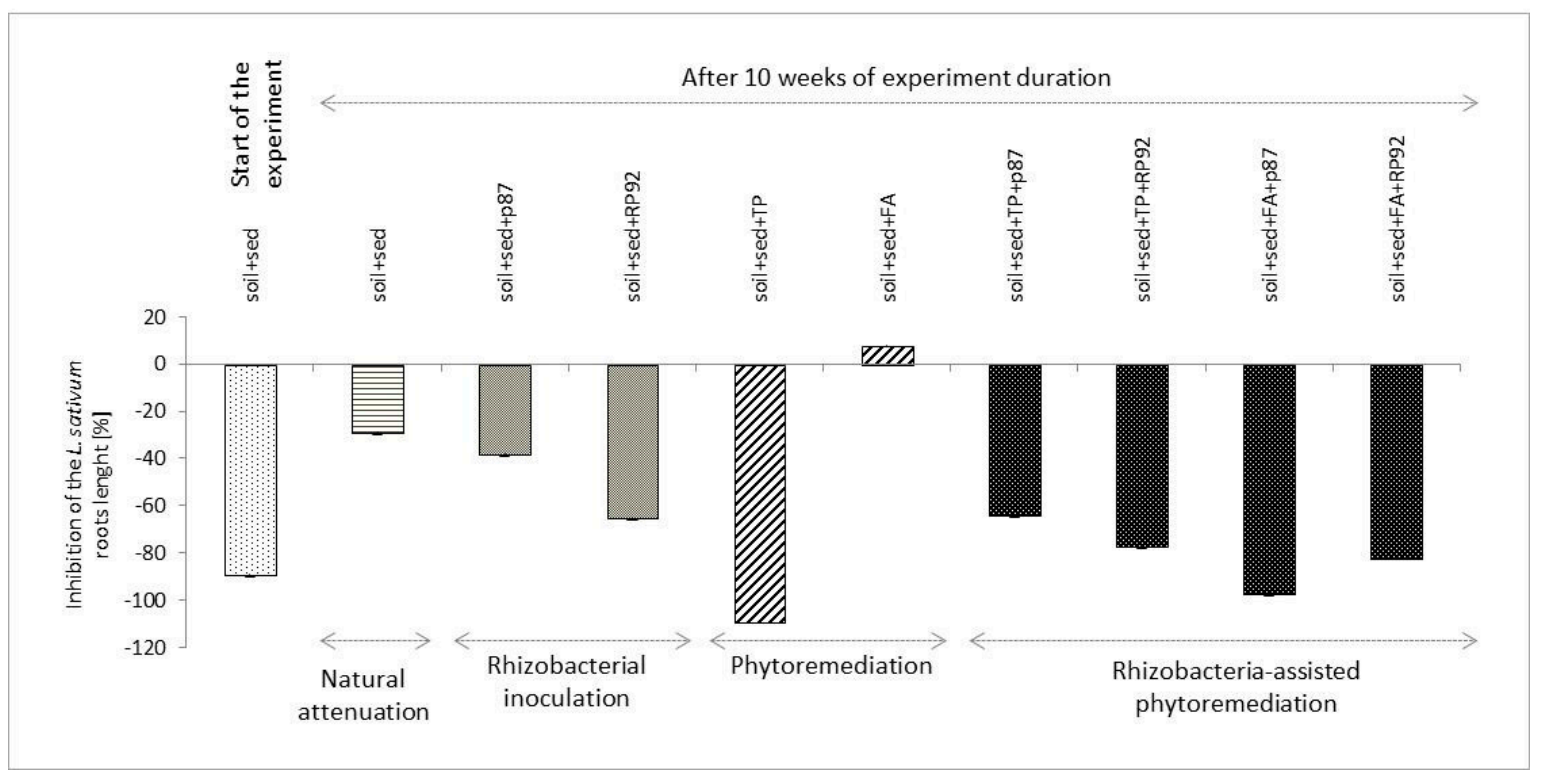

Figure 2. The effect of applied bioremediation strategies on soil phytotoxicity (negative values indicate stimulation of plant root growth).

The application of urban sediment led to nine-fold and seven-fold increases in the concentrations of the sum of 17 PCDDs/PCDFs congeners and TEQ in soil, respectively, in comparison to control soil (Table 1). The application of natural attenuation for 10 weeks increased the total PCDD/PCDF concentration by $47 \%$ (Figure 3A); however, TEQ concentration decreased by $14 \%$ in comparison to the initial value (Figure 3B). A similar situation was observed when the rhizobacterial strains were applied: Total PCDD/PCDF concentrations increased by $14 \%$ and $18 \%$ when p 87 and RP92 strains were applied (Figure 3A), while TEQ decreased by 23\% and 20\%, respectively (Figure 3B). The phytoremediation strategy was associated with a $24 \%$ (for T. patula) and $10 \%$ (for F. arundinacea) increase of total PCDD/PCDF level (Figure 2A), as well as a 23\% (for T. patula) and $21 \%$ (for F. arundinacea) decrease in TEQ value (Figure 3B).

The increasing total concentrations of PCDDs/PCDFs and the lowering of the TEQ values are related to the ongoing degradation processes. PCDDs/PCDFs are subject to both anaerobic and aerobic metabolism. Under anaerobic conditions, dechlorination of higher chlorinated congeners (mostly hexa-, hepta- and octa-chlorinated ones) of lower toxicity, reflected as low TEFs, occurs; while under aerobic conditions, lower chlorinated PCDDs/PCDFs, characterized by higher TEFs contributing in a higher extent to the TEQ, can be removed. Consequently, aerobic bacterial transformation led to the decrease in the content of lower chlorinated and thus more toxic congeners, thus leading to the reduction of the total TEQs in the studied samples.

The most effective approach, however, was the rhizobacteria-assisted phytoremediation strategy based on F. arundinacea. This strategy diminished the total concentration by $18 \%$ (when used with p87) or $8 \%$ (RP92) (Figure 3A), and PCDD/PCDF TEQ value by $44 \%$ (p87) or 36\% (RP92) (Figure 3B). Literature data also confirms the value of $F$. arundinacea for remediation purposes. Sun et al. [44] reported the degradation of polyaromatic hydrocarbons (PAHs) in soil treated with $F$. arundinacea. The authors demonstrated that $25 \%, 10 \%$ and $30 \%$ of 3-ring, 4-ring and 5(+6)-ring PAHs, respectively, were removed by $F$. arundinacea, while this value was $0.6 \%$ in unplanted soil. The application of $F$. arundinacea increased the soil PAH-degrading bacterial counts and microbial activity, suggesting that the plant can restore the microbiological functioning of PAH-contaminated soil. However, it must be stated that an essential step toward the biodegradation of a given compound is the expression of the respective degradative genes in bacteria. With this in mind, Siciliano et al. [45] reported greater induction of catabolic genes involved in naphthalene degradation in the rhizosphere soil of $F$. arundinacea than 
in unplanted soil. This clearly demonstrates the suitability of $F$. arundinacea in the remediation of organic compounds.
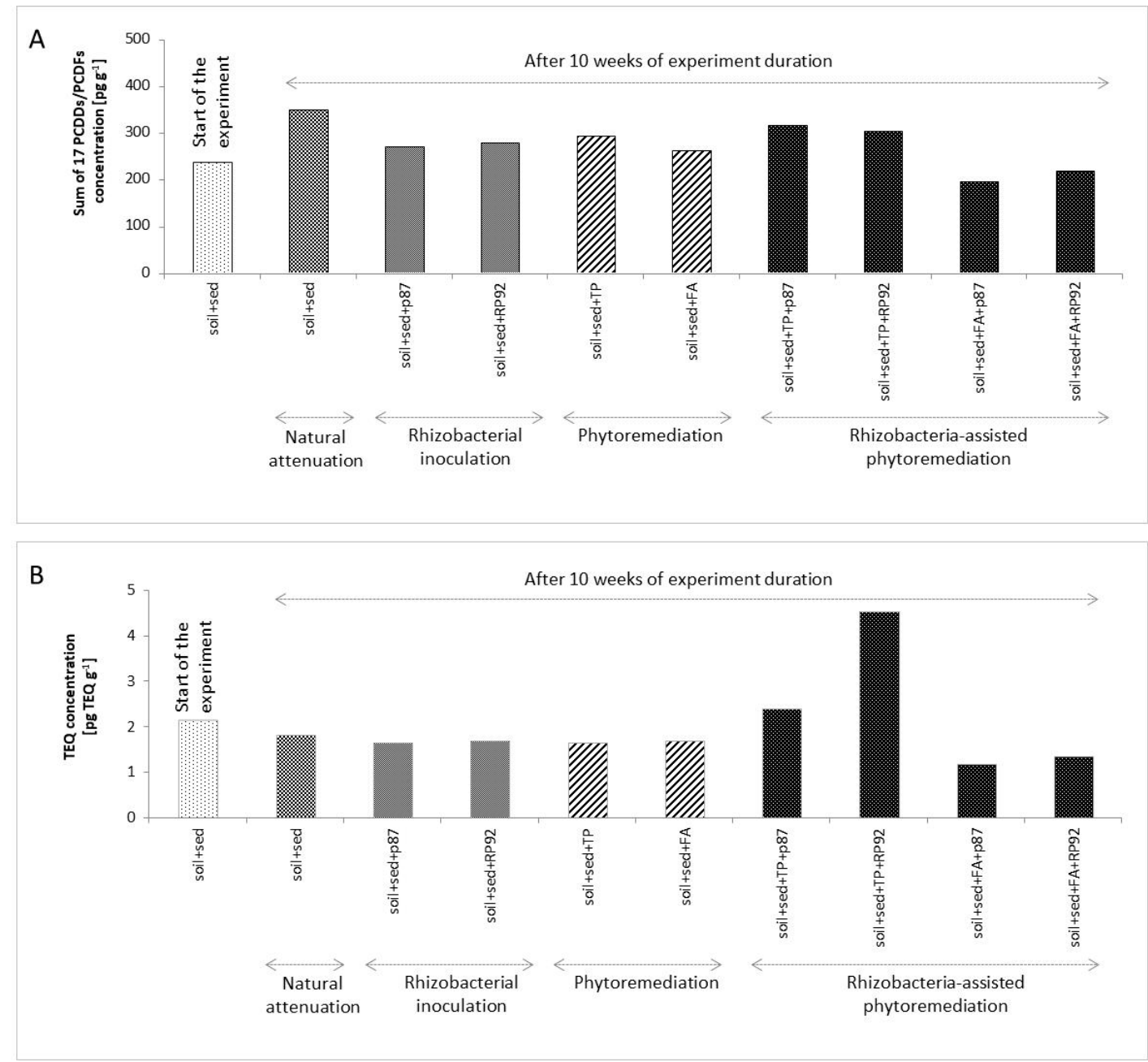

Figure 3. The effect of applied bioremediation strategies on changes in total (A) and TEQ (B) concentration of PCDDs/PCDFs.

The opposite was observed for the application of T. patula: Total values grew by $34 \%$ (p87) or $28 \%$ (RP92), and PCDD/PCDF TEQ values grew by 13\% (p87) or 113\% (RP92) (Figure 3A,B). Such increases in the total and TEQ values can be related to the transformation processes, which sometimes led to the production of intermediate compounds of higher toxicity than the parent congeners. In this case, the application of rhizobacteria-assisted phytoremediation strategy with T. patula, led to production of penta-chlorinated congeners (data not shown) characterized by higher toxicity in comparison to the hexa-, hepta- and octa-chlorinated compounds being the substrate for dechlorinating processes. The visual inspection of the soil-sediment samples planted with T. patula showed possible anoxic conditions therein (compacted, impermeable soil), facilitating dechlorination of higher chlorinated congeners and production of lower chlorinated ones of higher TEFs.

The effectiveness of rhizosphere biodegradation depends on the ability of microorganisms to adapt to a given pollutant concentration and their ability to colonize roots [46]. Kuiper et al. [47] demonstrated that naturally occurring rhizosphere biodegradation may be enhanced by the addition of microorganisms to the rhizosphere. Concluding this, in our case, both rhizobacterial inoculation and phytoremediation strategies gave similar outcomes, resulting in around a $20 \%-23 \%$ decline in the TEQ value. The similar effects of these strategies may be related to the fact that both led to an increase in the 
activity of soil microbiota: Rhizobacterial inoculation through the artificial addition of selected strains capable of degrading the given pollutant, and phytoremediation/rhizoremediation through the existing interactions between plant exudates, soil and microorganisms. The most promising solution seems to be the rhizobacteria-assisted phytoremediation strategy; however, among the used ornamentals, only F. arundinacea demonstrated the capacity to reduce both PCDD/PCDF total and TEQ levels. T. patula, in turn, despite its positive influence on PCDD/PCDF reduction, when used alone as part of the phytoremediation strategy, increased the total and TEQ concentration when used in combination with the bacterial inoculation.

\subsection{The Effects of Urban Sediment Amendments and Applied Remediation Strategies on the Biomass and Physiological Parameters of T. patula L. and F. arundinacea}

Pollutant concentration in the soil is certainly a key factor determining plant tolerance or sensitivity. Nevertheless, other factors such as metal speciation, the composition of heterogeneous hydrocarbon fractions, soil-pollutant and pollutant-pollutant interactions, also have to be considered. Another aspect is the protective character of the rhizosphere microbiota, which plays an intrinsic role in the protection of plants against pathogens and stress caused by excessive concentrations of pollutants and eases the uptake of biogenic substances by a given plant $[46,48,49]$.

From the perspective of the proper organization and management of the city space, it is important to select the most resistant plant species which both embellish the environment and resolve the pollution problem in the urban area. Therefore, the inoculation of existing soil microbiota with plant growth-promoting rhizobacteria, may not only improve plant growth, but also enhance phytoremediation rates by assisting in resource acquisition and modulating plant hormone levels, and/or by decreasing the inhibitory effects of pathogens $[15,50,51]$.

In our case, the cultivation of T. patula and F. arundinacea following the application of urban sediments to soil led to different plant responses. T. patula demonstrated $67 \%$ lower biomass when grown in soil amended with urban sediments (Figure 4(A1,A2)). The inoculation of soil with bacterial strains alleviated the toxic effect caused by sediment application by $47 \%$ for $\mathrm{p} 87$ and $54 \%$ for RP92, in comparison to plants grown in non-inoculated soil. The addition of p87 and RP92 strains to soil following sediments application led to 2.4-fold and 2.6-fold higher production of plant biomass in comparison to non-inoculated samples (case of T. patula). At the same time, the inoculation did not influence the biomass of plants grown in uncontaminated soil (Figure 4(A1,A2)).

The obtained results demonstrated that soil inoculation had a positive influence on T. patula growth. Two-way ANOVA analysis showed that both the sediment admixture and inoculation have an influence on plant biomass. Also, Duncan post-hoc test confirmed the significantly higher biomass of plants grown in soil with sediments and inoculation, however, no differences were found between used inoculants ( $\mathrm{p} 87$ vs. RP92). Samples without sediment demonstrated no statistically significant changes (Figure 4(A1)). Although it has been proposed to use T. patula as phytoremediation tool for dyes, tannery solid waste [52], soil co-contaminated by benzo[a]pyrene and metals [20], there is a considerable lack of information regarding the impact of bacterial inoculation on its growth and morphology. However, Agnello et al. [15] reported that bioaugmentation has a positive influence on plant biomass: they noted that bioaugmentation with $P$. aeruginosa had a positive effect on alfalfa biomass production, resulting in an increase of shoot biomass by as much as $56 \%$ and of root biomass by $105 \%$.

In the case of $F$. arundinacea, the plant grown in amended soil showed only $6 \%$ lower biomass than the plants grown in uncontaminated soil. The inoculation with $\mathrm{p} 87$ strain did not give any positive or negative response, while inoculation with RP92 strain led to $6 \%$ higher plant biomass in comparison to plants growing on untreated soil. In contrast to T. patula, F. arundinacea demonstrated slight decreases in biomass when grown in inoculated unpolluted soil (3\% for $\mathrm{p} 87$ and $11 \%$ for RP92), but no such changes were observed for plants grown in sediment-amended soil (Figure 4(A2)). However, the obtained results were not statistically significant (two-way ANOVA). 
Tagetes patula
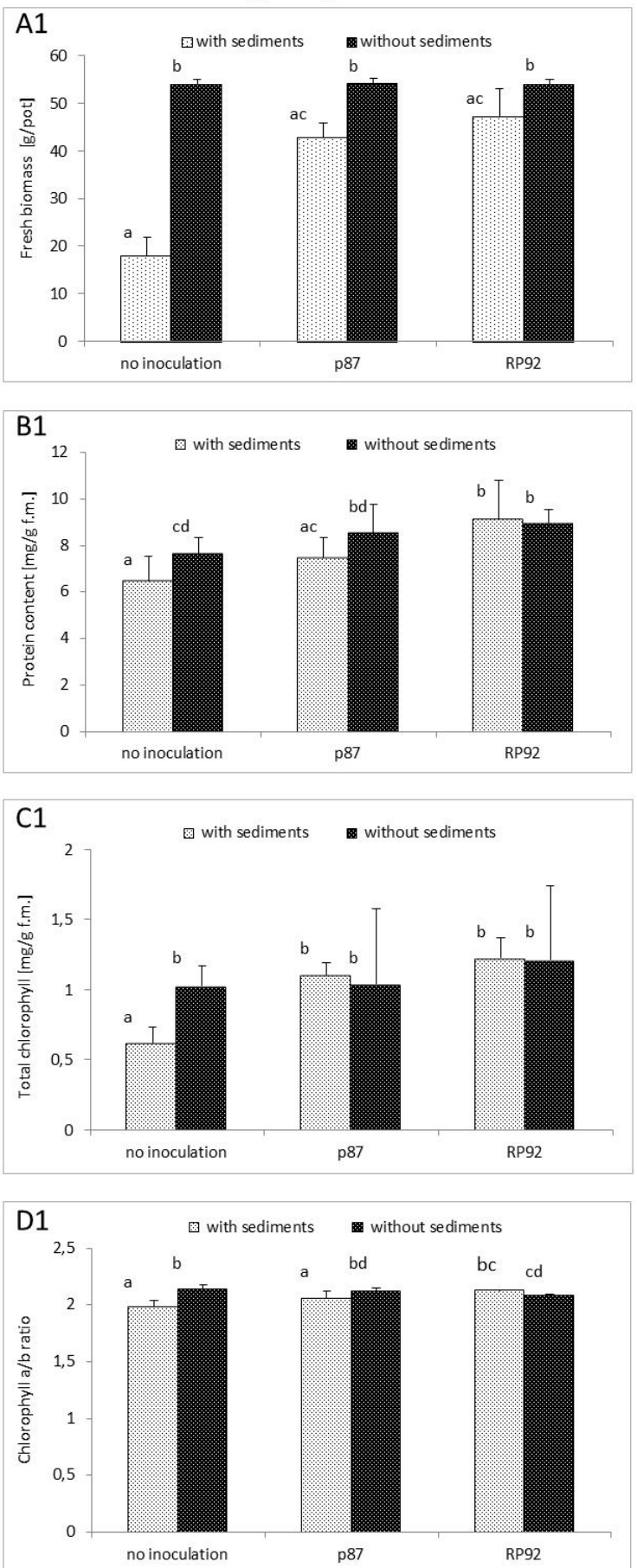

Festuca arundinacea
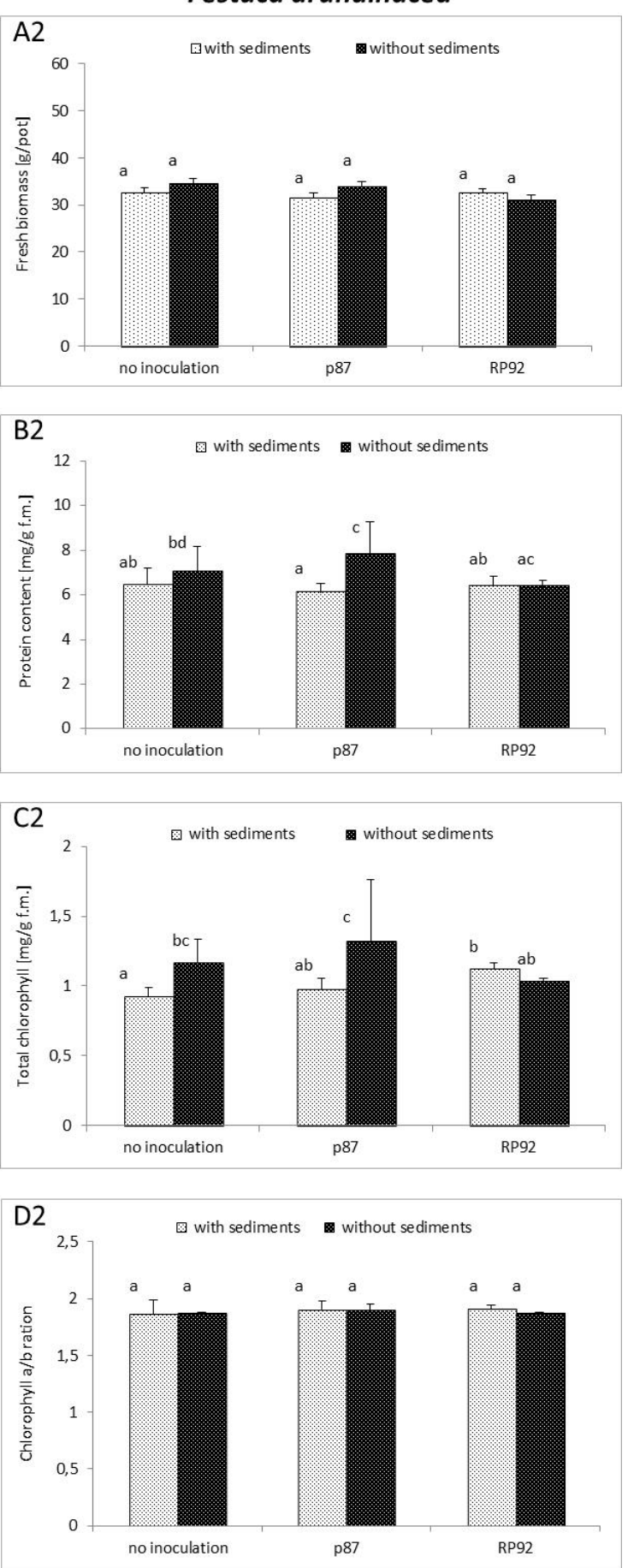

Figure 4. The effect of applied sediments and inoculation of growing medium (soil) with two bacterial strains p87 and RP92 on fresh biomass (A1,A2), protein content $(\mathbf{B} 1, \mathbf{B} 2)$, chlorophyll content $(\mathbf{C} 1, \mathbf{C} 2)$ and chlorophyll a/b ratio $(\mathbf{D} 1, \mathbf{D} 2)$ in the leaf tissues of T. patula and F. arundinacea (at $p<0.05$, the Duncan post-hoc test, the same letters indicate no statistically significant differences).

While morphological observation of the plant did not reveal the toxic effects related to the use of sediment or bacterial strains, a more diversified response was found when analyzing physiological parameters such as protein content, due to the greater sensitivity and higher degree of response to applied remediation techniques, and the range of compounds present in the sediments. 
T. patula grown in sediment-amended soil showed an increase in soluble protein content. Two-way ANOVA confirmed the influence of both sediment amendment and bacterial inoculation on the protein content. The results showed that inoculation with bacterial strains led to a significant increase (Duncan post-hoc test) in protein content being 115\% (for p87) and 141\% (for RP82) of control values (Figure 4(B1)). In the non-inoculated soil samples, the protein content of T. patula was $15 \%$ lower in variants fertilized with sediment than in the unfertilized ones. The obtained differences were statistically significant (Duncan post-hoc test).

In contrast, in the case of $F$. arundinacea, sediments had a significant influence on protein content (two-way ANOVA), while inoculation did not affect it. Duncan post-hoc test, however, revealed the statistically significant difference in variant inoculated with p 87 and no sediment admixture. In this case, application of p87 strain to the unamended soil led to a $12 \%$ increase in the protein content, while simultaneous application of both p87 and sediment resulted in lowering the protein content (Figure 4(B2)).

From the physiological point of view, it is known that soluble protein content decreases as plant senescence-related processes continue [53,54]. This is related to the initiation of the N-remobilization process, during which proteinase activity increases, leading to the degradation of protein to amino acids. The resulting amino acids and/or peptides are then transported through the phloem sap to the growing organs [55]. With this in mind, the increase in soluble protein content observed in T. patula tissues grown in inoculated soil may indicate a delay of senescence processes. This increase in soluble protein content is particularly noticeable after sediment application. Considering the toxicity of the sediment used in the experiment, the above described relationship can also indicate that the introduced rhizobacterial strains have a protective effect on studied plants that is reflected in the prevention of plant premature senescence. RP92 proved to have a stronger protective effect in this case.

In the case of total chlorophyll content of T. patula, two-way ANOVA demonstrated that sediments have no influence, unlike the type of inoculation that was found to significantly affect the content of chlorophyll. Duncan post-hoc test demonstrated, in turn, that the use of urban sediment significantly lowered the total chlorophyll content in green tissues of T. patula grown in non-inoculated variant, being only $60 \%$ of that of the value measured in plants grown in non-amended soil (Figure $4(\mathrm{C} 1)$ ). In this case, the inoculation of sediment-amended soil with p87 and RP92 significantly increased the chlorophyll content to $178 \%$ and $198 \%$ of non-inoculated and unamended control, respectively (Duncan post-hoc test). Moreover, RP92 increased the chlorophyll content even in non-fertilized plants to $118 \%$ of non-amended and non-inoculated control values; however, this increase was not statistically significant (Figure 4(C1)). Regarding the chlorophyll a/b ratio, the two-way ANOVA confirmed the influence of both the sediment admixture and inoculation on the obtained results. Duncan post-hoc test revealed significantly higher chlorophyll $\mathrm{a} / \mathrm{b}$ ratio in plants grown in soil amended with sediment and inoculated with RP92, in comparison to non-inoculated samples as well as ones inoculated with p87 (both amended with sediments) (Figure 4(C1)). The unamended samples inoculated with RP92 demonstrated a significantly lower chlorophyll $\mathrm{a} / \mathrm{b}$ ratio, when compared to the unamended and non-inoculated sample (Figure 4(C1)).

For F. arundinacea, two-way ANOVA demonstrated a contrary effect to T. patula: In this case, the chlorophyll content was dependent on the sediment application, while no such effect was observed for inoculation. Duncan post-hoc test revealed the significant increase in the chlorophyll content in sediment amended samples, in comparison to unamended ones. Moreover, significantly higher chlorophyll content was observed in plants grown in soil amended with sediments and inoculated with RP92, in comparison to the non-inoculated variant (Figure 4(C2)). Inoculation with p87, in turn, led to significantly higher chlorophyll content, but only when compared with samples without sediments and without inoculation. In the case of chlorophyll $\mathrm{a} / \mathrm{b}$ ratio, the statistical analyses showed neither the influence of sediments application, nor the type of inoculation (Figure 4(D1,D2)).

Our findings indicate that the soil amended with the urban sediment caused a significant reduction of chlorophyll content in both T. patula and F. arundinacea; while soil inoculation with bacterial strains 
not only suppressed this effect, but also led to an increase in chlorophyll content in comparison to control samples. The decrease of the chlorophyll content observed in investigated plants due to the application of sediments may be related to the presence of xenobiotics in the sediment. The decrease in chlorophyll content in leaves is one of the first symptoms of plant senescence, during which the breakdown of the thylakoid membranes and degradation of thylakoid-bound proteins occur. Our findings suggest that the use of sediments can exacerbate this process, while the application of bacterial strains protects plants from premature senescence. Furthermore, the reduced chlorophyll a/b ratio may indicate the progress of the aging process of T. patula and F. arundinacea grown in soil treated with sediments without simultaneous inoculation. Similarly, Nath et al. [56] demonstrated a linear decrease of chlorophyll $\mathrm{a} / \mathrm{b}$ ratio in Arabidopsis thaliana during natural leaf senescence, along with a decrease in total chlorophyll content. The authors noted that with gradual senescence, differential degradation of chlorophyll a and chlorophyll $b$ leads to changes in chlorophyll $a / b$ ratio.

In conclusion, T. patula is more susceptible to the range of xenobiotics in the tested sediments, but the application of bacterial strains alleviated the phytotoxicity, especially the RP92 strain. The use of bacteria also gives positive results when the soil is not amended with sediment. In the case of $F$. arundinacea, the use of both sediment application and inoculation with rhizobacterial strains promotes a good plant physiological status; while in sediment-free soil, only strain p87 seems to be beneficial.

Author Contributions: Conceptualization, M.U., A.W., G.S., S.S.; methodology, M.U., A.W., G.S., S.S., P.K., M.Z.; validation, M.U., A.W., G.S., S.S., M.Z.; investigation M.U., A.W., G.S., S.S., M.Z.; resources, M.U., G.S., P.K.; data curation, M.U., G.S.; writing—original draft preparation, M.U., G.S.; writing—review and editing, M.U.; visualization, M.U.; supervision, M.U.; project administration, M.U., G.S.; funding acquisition, M.U., G.S.

Funding: The pot experiment was a part of Greenland project (FP7-KBBE-266124) financed by the European Commission under the Seventh Framework Programme for Research; the research was also conducted as a part of the Project IP2014 049273 financed by the Ministry of Science and Higher Education programme under the name "Iuventus Plus" for the years 2015-2017.

Conflicts of Interest: The authors declare no conflict of interest. The funders had no role in the design of the study; in the collection, analyses, or interpretation of data; in the writing of the manuscript, or in the decision to publish the results.

\section{References}

1. Foster, G.D.; Roberts, E.C., Jr.; Gruessner, B.; Velinsky, D.J. Hydrogeochemistry and transport of organic contaminants in an urban watershed of Chesapeake Bay (USA). Appl. Geochem. 2000, 15, 901-915. [CrossRef]

2. Im, S.H.; Kannan, K.; Matsuda, M.; Giesy, J.P.; Wakimoto, T. Sources and distribution of polychlorinated dibenzo-p-dioxins and dibenzofurans in sediment from Masay Bay, Korea. Environ. Toxicol. Chem. 2002, 21, 245-252. [CrossRef] [PubMed]

3. Jartun, M.; Ottesen, R.T.; Steinnes, E.; Volden, T. Runoff of particle bound pollutants from urban impervious surfaces studied by analysis of sediments from stormwater traps. Sci. Total. Environ. 2008, 396, 147-163. [CrossRef] [PubMed]

4. Krishnappan, B.G.; Marsalek, J. Modelling of flocculation and transport of cohesive sediment from an on-stream stormwater detention pond. Water Res. 2002, 36, 3849-3859. [CrossRef]

5. Urbaniak, M.; Zieliński, M.; Ligocka, D.; Zalewski, M. A comparative analysis of selected Persistent Organic Pollutants (POPs) in reservoirs of different types of anthropopression-Polish and Ethiopian studies. Fresenius Environ. Bull. 2010, 19, 2710-2718.

6. Urbaniak, M.; Kiedrzyńska, E.; Zalewski, M. The role of a lowland reservoir in the transport of micropollutants, nutrients and the suspended particulate matter along the river continuum. Hydrol. Res. 2010, 43, 400-411. [CrossRef]

7. Urbaniak, M.; Zieliński, M.; Kaczkowski, Z.; Zalewski, M. Spatial distribution of PCDDs, PCDFs and dl-PCBs along the cascade of urban reservoirs. Hydrol. Res. 2012, 44, 614-630. [CrossRef]

8. Urbaniak, M.; Kiedrzyńska, E.; Zieliński, M.; Tołoczko, W.; Zalewski, M. Spatial distribution and reduction of PCDD/PCDF Toxic Equivalents along the three shallow lowland reservoirs. Environ. Sci. Pollut. Res. 2014, 21,4441-4452. [CrossRef] 
9. Urbaniak, M.; Kiedrzyńska, E.; Kiedrzyński, M.; Zieliński, M.; Grochowalski, A. The role of hydrology in the polychlorinated dibenzo-p-dioxin and dibenzofuran distributions in a lowland river. J. Environ. Qual. 2015, 44, 1171-1182. [CrossRef]

10. Urbaniak, M.; Tygielska, A.; Krauze, K.; Mankiewicz-Boczek, J. Effects of Stormwater and Snowmelt Runoff on ELISA-EQ Concentrations of PCDD/PCDF and Triclosan in an Urban River. PLoS ONE 2016, 11, 0151756. [CrossRef]

11. Wagner, I.; Zalewski, M. Ecohydrology as a Basis 1 for the Sustainable City Strategic Planning-Focus on Lodz, Poland. Rev. Environ. Sci. Bio/Technol. 2009, 8, 209-217. [CrossRef]

12. Wagner, I.; Zalewski, M. System solutions in urban water management: The Lodz (Poland) perspective. In Water Sensitive Cities; Howe, C., Mitchel, C., Eds.; IWA Publishing: London, UK, 2011; pp. 231-245.

13. European Parliament, Council of the European Union. Directive of the European Parliament and the Council 2013/39/EC of 12 August 2013 Amending Directive 2000/60/EC and 2008/105/EC in Respect of Priority Substances in the Field of Water Policy. 2013. Available online: https://eur-lex.europa.eu/LexUriServ/ LexUriServ.do?uri=OJ:L:2013:226:0001:0017:EN:PDF (accessed on 19 September 2019).

14. Briggs, G.G.; Bromilow, R.H.; Evans, A.A. Relationships between lipophilicity and root uptake and translocation of non-ionised chemicals by barley. Pestic. Sci. 1982, 13, 495-504. [CrossRef]

15. Agnello, A.; Bagard, M.; Van Hullebusch, E.; Esposito, G.; Huguenot, D. Comparative bioremediation of heavy metals and petroleum hydrocarbons co-contaminated soil by natural attenuation, phytoremediation, bioaugmentation and bioaugmentation-assisted phytoremediation. Sci. Total. Environ. 2016, 563, 693-703. [CrossRef] [PubMed]

16. Huguenot, D.; Bois, P.; Cornu, J.Y.; Jezeguel, K.; Lollier, M.; Lebeau, T. Remediation of sediment and water contaminated by copper in small-scaled constructed wetlands: Effect of bioaugmentation and phytoextraction. Environ. Sci. Pollut. Res. 2015, 22, 721-732. [CrossRef] [PubMed]

17. Glick, B.R. Using soil bacteria to facilitate phytoremediation. Biotechnol. Adv. 2010, 28, 367-374. [CrossRef] [PubMed]

18. Lin, X.; Li, X.; Li, P.; Li, F.; Zhang, L.; Zhou, Q. Evaluation of Plant-Microorganism Synergy for the Remediation of Diesel Fuel Contaminated Soil. Bull. Environ. Contam. Toxicol. 2008, 81, 19-24. [CrossRef] [PubMed]

19. Khan, S.; Afzal, M.; Iqbal, S.; Khan, Q.M. Plant-bacteria partnerships for the remediation of hydrocarbon contaminated soils. Chemosphere 2013, 90, 1317-1332. [CrossRef] [PubMed]

20. Sun, Y.; Zhou, Q.; Xu, Y.; Wang, L.; Liang, X. Phytoremediation for co-contaminated soils of benzo[a]pyrene $(\mathrm{B}[\mathrm{a}] \mathrm{P})$ and heavy metals using ornamental plant Tagetes patula. J. Hazard. Mater. 2011, 186, 2075-2082. [CrossRef] [PubMed]

21. Suresh, B.; Bais, H.; Raghavarao, K.; Ravishankar, G.; Ghildyal, N. Comparative evaluation of bioreactor design using Tagetes patula L. hairy roots as a model system. Process. Biochem. 2005, 40, 1509-1515. [CrossRef]

22. Vasudevan, P.; Kashyap, S.; Sharma, S. Tagetes: A multipurpose plant. Bioresour. Technol. 1997, 62, 29-35. [CrossRef]

23. Cruz-Fernandes, A.; Tomasini-Compocosio, A.; Perez-Flores, L.J.; Fernandez-Perrino, F.J.; Gutierrez-Rojas, M. Inoculation of seed-borne fungus in the rhizosphere of Festuca arundinacea promotes hydrocarbon removal and pyrene accumulation in roots. Plant Soil 2013, 362, 261-270. [CrossRef]

24. Xiao, N.; Liu, R.; Jin, C.; Dai, Y. Efficiency of five ornamental plant species in the phytoremediation of polycyclic aromatic hydrocarbon (PAH)-contaminated soil. Ecol. Eng. 2015, 75, 384-391. [CrossRef]

25. Balseiro-Romero, M.; Gkorezis, P.; Kidd, P.S.; Vangronsveld, J.; Monterroso, C. Enhanced degradation of diesel in the rhizosphere of Lupinus luteus after inoculation with diesel degrading and PGP bacterial strains. J. Environ. Qual. 2016, 45, 924-932. [CrossRef] [PubMed]

26. Becerra-Castro, C.; Kidd, P.; Prieto-Fernández, Á.; Weyens, N.; Acea, M.; Vangronsvel, J. Endophytic and rhizoplane bacteria associated with Cytisus striatus growing on hexachlorocyclohexane-contaminated soil: Isolation and characterisation. Plant Soil 2011, 340, 413-433. [CrossRef]

27. Becerra-Castro, C.; Monterroso, C.; Prieto-Fernandez, A.; Rodríguez-Lamas, L.; Loureiro-Viñas, M.; Acea, M.; Kidd, P. Pseudometallophytes colonising $\mathrm{Pb} / \mathrm{Zn}$ mine tailings: A description of the plant-microorganism-rhizosphere soil system and isolation of metal-tolerant bacteria. J. Hazard. Mater. 2012, 217, 350-359. [CrossRef] [PubMed] 
28. Szklarek, S.; Wagner, I.; Jurczak, T.; Zalewski, M. Sequential Sedimentation-Biofiltration System for the purification of a small urban river (the Sokolowka, Lodz) supplied by stormwater. J. Environ. Manag. 2018, 205, 201-208. [CrossRef]

29. Negussie, Y.Z.; Urbaniak, M.; Szklarek, S.; Lont, K.; Gagała, I.; Zalewski, M. Efficiency analysis of two sequential biofiltration systems in Poland and Ethiopia-The pilot study. Ecohydrol. Hydrobiol. 2012, 12, 271-285. [CrossRef]

30. Mergeay, M.; Nies, D.; Schlegel, H.G.; Gerits, J.; Charles, P.; Van Gijsegem, F. Alcaligenes eutrophus CH34 is a facultative chemolithotroph with plasmid-bound resistance to heavy metals. J. Bacteriol. 1985, 162, 328-334.

31. Polish Committee for Standardization. Emission from Stationary Sources. Determination of PCDD/PCDF Mass Concentration. PRT 3: Identification and Quantification; PN-EN 1948-3; PKN: Warsaw, Poland, 2006. (In Polish)

32. EPA. Method 1613, Tetra through Octa chlorinated dioxins and furans by Isotope dilution HRGC/HRMS; Revision B; US EPA: Washington, DC, USA, 1994.

33. Van den Berg, M.; Birnbaum, L.S.; Denison, M.; De Vito, M.; Farland, W.; Feeley, M.; Fiedler, H.; Hakansson, H.; Hanberg, A.; Haws, L.; et al. The 2005 World Health Organization Re-evaluation of Human and Mammalian Toxic Equivalency Factors for Dioxins and Dioxin-like Compounds. Toxicol. Sci. 2006, 93, 223-241. [CrossRef]

34. Van den Berg, M. The $2005 \mathrm{WHO}$ re-evaluation of toxic equivalency factors for dioxin like compounds-Implications for risk assessment and limitations of the concept. Toxicol. Letters 2006, 164, S55-S56. [CrossRef]

35. Phytotoxkit, Seed Germination and Early Growth Microbiotest with Higher Plants; MicroBioTest Inc.: Nazareth, Belgium, 2004.

36. Persoone, G.; Maršálek, B.; Blinova, I.; Torokne, A.; Zarina, D.; Manusadžianas, L.; Nalecz-Jawecki, G.; Tofan, L.; Stepanova, N.; Tothova, L.; et al. A practical and user-friendly toxicity classification system with microbiotests for natural waters and wastewaters. Environ. Toxicol. 2003, 18, 395-402. [CrossRef] [PubMed]

37. Bradford, M.M. A rapid and sensitive method for the quantification of microgram quantities of protein utilizing the principle of protein-dye binding. Anal. Biochem. 1976, 72, 248-254. [CrossRef]

38. Porra, R.; Thompson, W.; Kriedemann, P. Determination of accurate extinction coefficients and simultaneous equations for assaying chlorophylls $\mathrm{a}$ and $\mathrm{b}$ extracted with four different solvents: Verification of the concentration of chlorophyll standards by atomic absorption spectroscopy. Biochim. Et Biophys. Acta (Bba)_Bioenerg. 1989, 975, 384-394. [CrossRef]

39. Toth, G.; Jones, A.; Montanarella, L. LUCAS Topsoil Survey Methodology. Data and Results; JRC Technical Reports; Publications Office of the European Union: Luxembourg, 2013.

40. MacDonald, D.; Ingersoll, C.; Berger, T. Development and evaluation of consensus- based sediment development and evaluation of consensus-based sediment quality guidelines for freshwater ecosystems. Arch. Environ. Contam. Toxicol. 2000, 39, 20-31. [CrossRef] [PubMed]

41. Baran, A.; Tarnawski, M. Phytotoxkit/Phytotestkit and Microtox ${ }^{\circledR}$ as tools for toxicity assessment of sediments. Ecotoxicol. Environ. Saf. 2013, 98, 19-27. [CrossRef]

42. Chen, Y.; Zhu, G.; Tian, G.; Zhou, G.; Luo, Y.; Wu, S. Phytotoxicity of dredged sediment from urban canal as land application. Environ. Pollut. 2002, 117, 233-241. [CrossRef]

43. Czerniawska-Kusza, I.; Kusza, G. The potential of the Phytotoxkit microbiotest for hazard evaluation of sediments in eutrophic freshwater ecosystems. Environ. Monit. Assess. 2011, 179, 113-121. [CrossRef]

44. Sun, M.; Fu, D.; Teng, Y.; Shen, Y.; Luo, Y.; Li, Z.; Christie, P. In situ phytoremediation of PAH-contaminated soil by intercropping alfalfa (Medicago sativa L.) with tall fescue (Festuca arundinacea Schreb.) and associated soil microbial activity. J. Soils Sediments 2011, 11, 980-989. [CrossRef]

45. Siciliano, S.D.; Germida, J.J.; Banks, K.; Greer, C.W. Changes in microbial community composition and function during a polyaromatic hydrocarbon phytoremediation field trial. Appl. Environ. Microbiol. 2003, 69, 483-489. [CrossRef]

46. Macek, T.; Macková, M.; Káš, J. Exploitation of plants for the removal of organics in environmental remediation. Biotechnol. Adv. 2000, 18, 23-34. [CrossRef]

47. Kuiper, I.; Lagendijk, E.L.; Bloemberg, G.V.; Lugtenberg, B.J.J. Rhizoremediation: A Beneficial Plant-Microbe Interaction. Mol. Plant-Microbe Interact. 2004, 17, 6-15. [CrossRef] [PubMed]

48. Lugtenberg, B.J.; Dekkers, L.; Bloemberg, G.V. Molecular determinants of rhizosphere colonization by Pseudomonas. Ann. Rev. Phytopathol. 2001, 39, 461-490. [CrossRef] [PubMed] 
49. Whipps, J.M. Carbon economy. In The Rhizosphere; Lynch, J.M., Ed.; Wiley: New York, NY, USA, 1990; pp. 59-97.

50. Ahemad, M.; Kibret, M. Mechanisms and applications of plant growth promoting rhizobacteria: Current perspective. J. King Saud Univ. Sci. 2014, 26, 1-20. [CrossRef]

51. Puga-Freitas, R.; Blouin, M. A review of the effects of soil organisms on plant hormone signalling pathways. Environ. Exp. Bot. 2015, 114, 104-116. [CrossRef]

52. Firdaus-e-Bareen; Nazir, A. Metal decontamination of tannery solid waste using Tagetes patula in association with saprobic and mycorrhizal fungi. Environmentalist 2010, 30, 45-53. [CrossRef]

53. Camp, P.J.; Huber, S.C.; Burke, J.J.; Moreland, D.E. Biochemical Changes that Occur during Senescence of Wheat Leaves. Plant Physiol. 1982, 70, 1641-1646. [CrossRef] [PubMed]

54. Romanova, A.K.; Semenova, G.A.; Ignat'ev, A.R.; Novichkova, N.S.; Fomina, I.R. Biochemistry and cell ultrastructure changes during senescence of Beta vulgaris L. leaf. Protoplasma 2016, 253, 719-727. [CrossRef]

55. Girondé, A.; Poret, M.; Etienne, P.; Trouverie, J.; Bouchereau, A.; Le Cahérec, F.; Leport, L.; Orsel, M.; Niogret, M.-F.; Deleu, C.; et al. A profiling approach of the natural variability of foliar $\mathrm{N}$ remobilization at the rosette stage gives clues to understand the limiting processes involved in the low $\mathrm{N}$ use efficiency of winter oilseed rape. J. Exp. Bot. 2015, 66, 2461-2473. [CrossRef]

56. Nath, K.; Phee, B.-K.; Jeong, S.; Lee, S.Y.; Tateno, Y.; Allakhverdiev, S.I.; Lee, C.-H.; Gil Nam, H. Age-dependent changes in the functions and compositions of photosynthetic complexes in the thylakoid membranes of Arabidopsis thaliana. Photosynth. Res. 2013, 117, 547-556. [CrossRef]

(C) 2019 by the authors. Licensee MDPI, Basel, Switzerland. This article is an open access article distributed under the terms and conditions of the Creative Commons Attribution (CC BY) license (http://creativecommons.org/licenses/by/4.0/). 